ENERGY METHODS OF STRUCTURAL ANALYSIS 
By the same author

ESSENTIAL SOLID MECHANICS

Theory, Worked Examples and Problems 


\section{ENERGY METHODS OF STRUCTURAL ANALYSIS}

Theory, worked examples and problems

B. W. Young

Professor of Structural Engineering

Bayero University, Kano, Nigeria

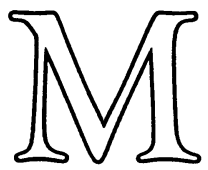


(C) B. W. Young 1981

All rights reserved. No part of this publication may be reproduced or transmitted, in any form or by any means, without permission.

First published 1981 by

THE MACMILLAN PRESS LTD

London and Basingstoke

Companies and representatives throughout the world

ISBN 978-0-333-27776-8 ISBN 978-1-349-05101-4 (eBook)

DOI 10.1007/978-1-349-05101-4

The paperback edition of this book is sold subject to the condition that it shall not, by way of trade or otherwise, be lent, resold, hired out, or otherwise circulated without the publisher's prior consent in any form of binding or cover other than that in which it is published and without a similar condition including this condition being imposed on the subsequent purchaser. 


\section{CONTENTS}

Preface

vii

1. PRELIMINARIES

1

1.1 Definitions of Strain Energy and Complementary

Energy

1.2 The Basic Energy Theorems

2

1.3 Potential Energy 5

$\begin{array}{ll}1.4 \text { Stationary Complementary Energy } & 7\end{array}$

1.5 Auxiliary Energy Theorems 9

2. FORCE AND DEFORMATION ANALYSIS OF PIN-JOINTED FRAMES 11

2.1 Energy Due to Axial Forces 11

2.2 Conversion of Statically Indeterminate Systems 12

$\begin{array}{ll}2.3 \text { Choice of Method of Analysis } & 14\end{array}$

$\begin{array}{ll}2.4 \text { The Compatibility Method } & 14\end{array}$

$\begin{array}{ll}2.5 \text { The Equilibrium Method } & 37\end{array}$

2.6 Deflexions in Pin-jointed Frames $\quad 50$

$\begin{array}{ll}2.7 \text { Design Example } & 60\end{array}$

$\begin{array}{ll}2.8 \text { Problems } & 66\end{array}$

3. FORCE AND DEFORMATION ANALYSIS OF BEAMS, CURVED MEMBERS $\begin{array}{lr}\text { AND RIGID-JOINTED FRAMES } & 80\end{array}$

3.1 Complementary Energy Due to Bending 80

$\begin{array}{ll}3.2 \text { Straight Beams } & 81\end{array}$

3.3 Curved Members $\quad 86$

3.4 Rigid-jointed Plane Frames 105

$\begin{array}{ll}3.5 \text { Design Example } & 114\end{array}$

$\begin{array}{ll}3.6 \text { Problems } & 120\end{array}$ 
4. POTENTIAL ENERGY METHODS

4.1 Conditions for Equilibrium : A Case Study

4.2 Structural Systems with a Limited Number of Degrees of Freedom 133

4.3 Approximate Solutions: The Rayleigh-Ritz Method 134

4.4 Design Example 154

$\begin{array}{ll}4.5 \text { Problems } & 161\end{array}$

Index 


\section{PREFACE}

A wide variety of different methods of structural analysis exist although many of them are designed for the solution of particular types of problem. Two procedures, however, are generally applicable; these are the method of virtual work and energy methods. In essence, the two methods are equivalent since, although the arguments used in establishing the governing equations differ, the equations themselves are identical.

In the author's experience, students studying virtual work find some difficulty in coming to terms with the idea of hypothetical forces or deformations whereas they quickly grasp the more obvious physical interpretations of the energy approach. One additional advantage that energy methods have over virtual work is their application to the approximate solution of complex problems for which exact solutions may not exist.

Energy methods have not received the consideration they deserve in the literature and it is for this reason that this book has been written. The few acceptable textbooks which treat the subject are at a level which is not easily accessible to undergraduates. It is a matter of regret that most undergraduate textbooks which do deal with energy methods generally reveal a hazy understanding of the principles and fail to take full advantage of their potential.

Energy methods have applications in almost every branch of structural analysis, as well as in many other fields. It is therefore essential that the undergraduate engineer should be fully conversant with their use. At the same time, it must be remembered that there are certain alternative specialised methods of analysis which might be quicker or easier for the solution of particular problems; it is the reader's responsibility to ensure that he does not put all his eggs in one basket.

This book is intended for second and third-year undergraduates in university or polytechnic degree courses. It should also prove useful as a source of reference to designers in practice. The format follows that of the author's previous book in this series, Essential Solid Mechanics; the theory, in concise form, is followed by a number of worked examples chosen to illustrate all the principles involved. Each chapter (except the first) ends with a selection of problems with answers which the reader may use for practice. The examples and problems are typical of those set in examinations at the end of the second or third years of a degree course. In some cases the precise origin of the questions is unknown but general acknowledgement is given here. The author alone is responsible for the solutions and answers.

One feature which will be of particular interest to both finalyear undergraduates and practising designers is the design example which completes each of the three main chapters. Here an attempt 
has been made to create real-1ife design problems which may be solved by the application of energy methods. These examples must not be confused with the examination type of question.

B. W. YOUNG

\section{ACKNOWLEDGEMENTS}

For the proofs of Castigliano's first theorem (part I) and the first theorem of complementary energy, acknowledgement is made to Stephen Timoshenko and James Gere, on whose presentation (in Mechanics of Materials, Van Nostrand Reinhold, 1972) it would be impossible to improve. 